\title{
Occupational Health and Safety Protection (K3) for Women Workers in The City of Makassar
}

\author{
Mustari* \\ Departemen of Pancasila and Civic \\ Education \\ Faculty of Social Science \\ State University of Makassar \\ Makassar, Indonesia \\ mustari6508@unm.ac.id
}

\author{
Muhammad Akbal \\ Departemen of Pancasila and Civic \\ Education \\ Faculty of Social Science \\ State University of Makassar \\ Makassar, Indonesia \\ m.akbal@ unm.ac.id
}

\author{
Firman Umar \\ Departemen of Pancasila and Civic \\ Education \\ Faculty of Social Science \\ State University of Makassar \\ Makassar, Indonesia \\ firman.umar@unm.ac.id
}

\begin{abstract}
This study aims to determine the implementation of $\mathrm{K3}$ protection for female workers in Makassar City. The research method used is legal research methods with juridical, normative empirical approaches. The results of the study found that $\mathrm{K3}$ protection for female workers in the workplace refers to the International Labor Organization convention No. 111 of 1993 which was ratified in Law Number 21 of 1999, stipulating that all people should enjoy equality of opportunity and treatment with respect to employment, wages, improvements in employment, working hours and conditions, and access to training. The Makassar City Government has implemented K3 protection for female workers by following the provisions of the Manpower Law, Article 86 paragraph 1 states that every worker / laborer has the right to obtain protection for work safety; morals and morals and treatment in accordance with human dignity and religious values. The government, in this case the city and provincial manpower offices, provides K3 protection to female workers because it is considered that women have biological specialties that need special protection.
\end{abstract}

Keywords - Special protection, K3, Women Workers

\section{INTRODUCTION}

Protection of women workers in the workplace is expressly regulated in the International Labor Organization convention, hereinafter abbreviated as ILO No. 111 of 1993 which was ratified in Law Number 21 of 1999, stipulating that all people should enjoy equal opportunity and treatment with respect to employment, wages. , improvements in employment, working hours and conditions, and access to training.

All of this is especially important for women, who have traditionally been denied equal wages to better and safer jobs [1]. ILO Conventions. Number 105 which was ratified in Law Number 19 Year 1999 further stipulates that freedom of association, freedom from forced labor, and protection of workers against unsafe and unhealthy working conditions. These provisions are the provisions of the previous convention, namely the ILO Convention. Number 100 of 1951 which was ratified in Law Number 80 of 1957 , concerning equal wages for male and female workers / laborers for work of equal value, provides equality between the sexes in terms of wages and salaries [2].

Furthermore, Convention Number 111 of 1958 regulates Discrimination in Employment and Occupation, essentially eliminating the distinction of exclusion or favoritism on the basis of ethnicity, color, sex, religion, political views, social origin or nationality, which have the effect of weakening equal opportunities or treatment. in work and position. Regarding equal remuneration for male and female workers / laborers for work of equal value, providing equality between the sexes in terms of wages and salaries. Furthermore, Convention Number 111 of 1958 regulates Discrimination in Employment and Occupation, in essence eliminating the distinction of exclusion or favoritism on the basis of ethnicity, color, sex, religion, political views, social origin or nationality, which have the effect of weakening equal opportunities or treatment. in work and position [3][4].

Regarding equal remuneration for male and female workers / laborers for work of equal value, providing equality between the sexes in terms of wages and salaries. Furthermore, Convention Number 111 of 1958 regulates Discrimination in Employment and Occupation, in essence eliminating the distinction of exclusion or favoritism on the basis of ethnicity, color, sex, religion, political views, social origin or nationality, which have the effect of weakening equal opportunities or treatment. in work and position [5][6].

The current development of a new paradigm of national development, which is more directed towards integrative development, is known as "gender mainstreaming" or gender mainstreaming, stipulated in Presidential Instruction No. 9 of 2000 on gender mainstreaming in national development, this is the main strategy to ascertain whether women and men get access, participate have control, get equal and fair benefits in development.

Gender mainstreaming in national development explicitly states that "development planning with a gender perspective is basically an effort to transform gender mainstreaming into real activities of sectoral institutions and is an integral part of the functional activities of all government agencies and institutions at the central and regional levels. Presidential Instruction Number 9 of 2000 is strengthened by Law. Number 25 concerning the 2000-2004 National Development Program, which combines a gender perspective in several policies, programs and activities. Then the Inpres was followed up with [7].

Minister of Home Affairs Decree Number 132 of 2003 concerning general guidelines for the implementation of gender mainstreaming in regional development, was later 
replaced by Minister of Home Affairs Regulation Number 15 of 2008 concerning general guidelines for the implementation of gender mainstreaming in the regions.

Law Number 13 of 2003 concerning Manpower, hereinafter abbreviated as the Manpower Act, stipulates that manpower development must be based on Pancasila with the aim of empowering and empowering the workforce in an optimal and humane manner, as well as providing protection in realizing welfare [8]. The articles related to the protection of the normative rights of women workers are Article 76, to Article 85, regarding working time, Article 86, Article 87, concerning occupational safety and health, Article 88, to Article 98 concerning wages, Articles 99 to 101 concerning welfare.

\section{METHOD}

This research is a legal research using a normativeempirical juridical approach, through a study of legal theory and laws and regulations related to labor. Research location in Makassar City. The source of legal material for this research consists of three types, namely first, primary legal material in the form of labor legislation. Second, secondary legal material in the form of legal principles and legal theory. Third, tertiary legal materials in the form of articles or legal journals. The research data collection technique used interviews and document studies [9]. The legal materials that have been obtained are then carried out categorization or coding of data and analysis using qualitative analysis with a normative-empirical juridical approach to interpret these legal materials descriptively.

\section{RESULT AND DISCUSSION}

\section{A. Protection of the Occupational Health and Safety of} Women Workers (K3)

Based on Article 23 paragraph (1) of the DUHAM, it is stipulated that everyone has the right to work and is entitled to just and favorable labor conditions. In addition, Article 7 of the Covenant on the rights of, social, social and cultural affairs regulates everyone can enjoy safe and healthy working conditions. One indicator of safe and healthy labor conditions and working conditions is $\mathrm{K} 3$ protection. The two provisions that are regulated globally above, it is legally the state's obligation to follow up into the provisions of national legislation. One manifestation of the state's obligation to follow up on the global rules above is the provision of the labor law, Article 86 paragraph (1) stipulates that: Every worker / laborer has the right to obtain protection for work safety; morals and morals[10].

As a description of the number of workers in Makassar City, those who must get $\mathrm{K} 3$ protection are as follows:

Table 1. Number of female workers in Makassar Industrial Estate companies that receive protection

\begin{tabular}{|c|c|c|c|}
\hline No & Location & Company Name & $\begin{array}{c}\text { Nimber of } \\
\text { Female } \\
\text { Workers }\end{array}$ \\
\hline 1 & Kima 4 & PT. Cher Woo Fishery & 71 people \\
\hline
\end{tabular}

\begin{tabular}{|l|l|l|l|}
\hline 2 & Kima 10 & PT. Indofood & 324 people \\
\hline 3 & Kima10 & PT. Kantingen Timber Selebes & 1080 people \\
\hline 4 & Kima 6 & PT. Sout Suco & 182 people \\
\hline 5 & Kima 5 & PT. Bogatama Marinusa & 400 people \\
\hline 6 & Kima 8 & PT. Nusa Dwi Citra Tunggal & 79 people \\
\hline 7 & Kima 17 & PT. Sitto Lestari Jaya Sakti & 66 people \\
\hline 8 & Kima 5 & PT. Jaya mighty prosperous eternally & 44 people \\
\hline 9 & Kima 3 & PT. The glow of the East Star & 110 0rang \\
\hline 10 & Kima 5 & PT. Multi Monodon Indonesia & 106 people \\
\hline
\end{tabular}

Source: Makassar manpower office

In the table above, it can be seen that there are 10 companies that have quite large female workers located in the Makassar industrial area (KIMA).

Furthermore, the following table shows the types of $\mathrm{K} 3$ protection provided by the company.

Table 2. Types of K3 protection for female workers in companies located in the Makassar industrial area.

\begin{tabular}{|l|l|l|}
\hline $\begin{array}{c}\text { No } \\
\cdot\end{array}$ & \multicolumn{1}{|c|}{ Protection type } & \multicolumn{1}{c|}{ Information } \\
\hline 1 & $\begin{array}{l}\text { Protection of reproductive } \\
\text { function }\end{array}$ & $\begin{array}{l}\text { Giving and settingshour } \\
\text { break on pregnant and give } \\
\text { birth. }\end{array}$ \\
\hline 2 & $\begin{array}{l}\text { Providing opportunities } \\
\text { and facilities to breastfeed } \\
\text { their children }\end{array}$ & Provision of a nursing room \\
\hline 3 & $\begin{array}{l}\text { Work safety } \\
\text { and }\end{array}$ & $\begin{array}{l}\text { Provision various equipment work } \\
\text { at work }\end{array}$ \\
\hline 5 & $\begin{array}{l}\text { Treatment according to } \\
\text { human dignity and dignity } \\
\text { as well as religious values }\end{array}$ & $\begin{array}{l}\text { Provision of shuttle transportation } \\
\text { that returns to work between hours } \\
\text { 23.00 to 05.00 }\end{array}$ \\
\hline
\end{tabular}

Source: Research results 2018 - 2020

OHS protection or K3 norms. Based on data from labor inspectors, it is revealed that there has been no violation of the employer's obligation to provide $\mathrm{K} 3$ protection, meaning that there are no K3 violations [11]. According to Hasan Basry, even though there were no violations, the supervision of K3 norms was still and continues to be carried out. If there is a violation of $\mathrm{K} 3$ norms [12]. The action is the issuance of an inspection note to be followed up with the BAP by the labor inspector as a civil servant investigator (PPNS) as well as the imposition of sanctions on companies, which are based on the provisions of Law Number 7 of 1981 regulating compulsory labor reports in companies.

If one examines the requirements for company reporting, there are provisions for companies to report forms of labor protection, employment relations, working conditions, working conditions. Therefore, protection of workers can only run optimally, it is necessary to have strict supervision from the government, this supervision is part of the state's obligation to protect workers' rights in accordance with the spirit of the 1945 Constitution of the Republic of Indonesia Article 28 D paragraph (2) which regulates that every person has the right to work and to receive fair and proper compensation and treatment in an employment relationship. 
Law Number 7 of 1981 concerning the compulsory reporting of companies, in essence is an effort to make it easier to obtain data in accordance with developments regarding the condition of the workforce at each company, and will become information material for the government to be further processed as material for determining policies in the manpower sector. . In addition, with the existence of this Law, it is more directed to be able to meet the needs in accordance with the level of progress in all fields, so that legal certainty can be created and the implementation of development in the field of labor relations can be smooth[13].

Protection of female workers while working, according to the Head of the Regional Technical Implementation Unit of the K3 Certification Center. South Sulawesi Province, states that K3 protection for female workers is carried out in accordance with their dignity and status, and in accordance with the provisions stipulated in the manpower law [14][15].

The latest development of $\mathrm{K} 3$ protection has formed a regional occupational safety and health supervisory committee (P2K3) chaired by the Mayor, this institution is a follow-up to the provisions of Law Number 1 of 1970 concerning K3. The essence of the institution is to create OSH stability for workers, both male and female workers, so that OSH stability is expected to be created in the company.

So the essence of protection given to women workers, especially K3 protection, is none other than because of the existence of women workers as workers who have biological specificities, including reproductive functions, in the Covenant on Ecos, Social and Cultural Rights in article 7 it is called special protection. However, in reality there is still a misconception that special protection or "affirmative actions that are understood by employers, namely only revolving around the right to menstrual leave, maternity leave, abortion.

\section{CONCLUSION}

The protection of occupational health and safety (K3) for female workers has basically been carried out in companies in Makassar City that employ female workers, as regulated in the Law. No 13 Tanuh 2003 concerning manpower. and various other laws and regulations. In relation to these protection measures, the government is strictly carrying out the supervision carried out by the provincial labor inspectors by monitoring the violation of work norms. On the other hand, to maintain K3 protection for female workers, the government regulates it even more strictly with the issuance of Law Number 7 of 1981 concerning the obligation of companies to report employment problems in their respective companies.

\section{ACKNOWLEDGMENT}

We would like to extend highly appreciation to Rector of the State University of Makassar, Dean of the Faculty of Social Sciences, Makassar State University, Makassar City Manpower and Transmigration Office, Office of Manpower and Transmigration of South Sulawesi Province, Companies in the Makassar industrial area (KIMA) for sponsoring the writing of this article and to the research informants, who provided valuable information in this research.

\section{REFERENCES}

[1] F. D. Blau and L. M. Kahn, "The gender pay gap: Have women gone as far as they can?," Acad. Manag. Perspect., vol. 21, no. 1, pp. 7-23, 2007.

[2] S. Halford, M. Savage, and A. Witz, Gender, careers and organisations. Springer, 1997.

[3] S. R. L. Vargas, "Deconstructing homo [geneous] Americanus: The white ethnic immigrant narrative and its exclusionary effect," Tul. L. Rev., vol. 72, p. 1493, 1997.

[4] J. L. Grossman, "Women's Jury Service: Right of Citizenship or Privilege of Difference?," Stanford Law Rev., pp. 1115-1160, 1994.

[5] V. C. Plaut, "Diversity science: Why and how difference makes a difference," Psychol. Inq., vol. 21, no. 2, pp. 77-99, 2010.

[6] S. Awaliyah, "Law Review on Age Discrimination for Job Seekers in Indonesia," JL Pol'y Glob., vol. 63, p. 109, 2017.

[7] S. Schech and M. Mustafa, "The politics of gender mainstreaming poverty reduction: an Indonesian case study," Soc. Polit., vol. 17, no. 1, pp. 111-135, 2010.

[8] A. Number, "Year 2003 Concerning Manpower," Undang-Undang. Jakarta Kementeri. Tenaga Kerja dan Transm. Republik Indones., 13AD.

[9] P. Sugiyono, "Metodologi penelitian kuantitatif kualitatif dan R\&D," Alpabeta, Bandung, 2011.

[10] S. Wheeler, "Ethics in the workplace," Law Crit., vol. 18, no. 1, pp. 1-28, 2007.

[11] W. Yuhaeni, "The Legal Protection Towards Child Labour in an Attempt to Improve Their Work Safety and Health," Int. J. Sci. Soc., vol. 2, no. 1, pp. 188203, 2020.

[12] P. T. Kabamba and S. Hara, "Worst-case analysis and design of sampled-data control systems," IEEE Trans. Automat. Contr., vol. 38, no. 9, pp. 13371358, 1993.

[13] D. M. Trubek, "Toward a social theory of law: an essay on the study of law and development," Yale Law J., vol. 82, no. 1, pp. 1-50, 1972.

[14] M. Syukri, M. S. Mawardi, and A. Akhmadi, "A Qualitative Study on the Impact of the PNPM-Rural in East Java, West Sumatra, and Southeast Sulawesi," SMERU Research Institute, 2013.

[15] F. H. A. Shidieq, "Assessing the Efficiency of Health Facilities in Indonesia." University of Leeds, 2018. 